\title{
Appendicitis epidemic following introduction of piped water to Anglesey
}

\author{
D J P BARKER, JULIE A MORRIS, SHIRLEY J SIMMONDS, AND R H P OLIVER \\ From the MRC Environmental Epidemiology Unit, University of Southampton, Southampton General Hospital, \\ Southampton SO9 $4 X Y$ and Ysbyty Gwynedd, Penrhosgarnedd, Bangor, Gwynedd
}

SUMmaRY The extension of piped water supplies in Anglesey, North Wales, 30 years ago and the consequent introduction of domestic hot water systems was followed by an epidemic of appendicitis. This occurred while appendicitis rates were falling elsewhere in Britain. The diet of Anglesey is unremarkable. This is further evidence that epidemics of appendicitis occur during the transition to 'western' hygiene, an important component of which is the provision of domestic hot water systems and fixed baths.

It has been suggested that the steep rise in appendicitis rates in Britain at the beginning of this century was the result of the Public Health Acts in the late 1800 s. $^{1}$ Improvements in hygiene consequent upon improved water supplies, housing, and sanitation greatly reduced exposure of young children to enteric organisms, demonstrated by the fall in childhood mortality from diarrhoeal disease. It is postulated that this altered the response to enteric or respiratory infections in later childhood and adult life in such a way that they triggered acute appendicitis. The hypothesis suggests that the decline in appendicitis rates in Britain since the 1930 s is due to reduced encounters with triggering infections as a result of continued improvements in hygiene.

Response to the Public Health Acts was not uniform throughout Britain. In Anglesey, North Wales, improvements in hygiene came more slowly than in most areas. In 1939, a Ministry of Health report on tuberculosis concluded that "in spite of the efforts which have been made, the housing conditions in many parts of the county remain indescribably bad", the houses being unusually small and overcrowded. ${ }^{2} \mathrm{~A}$ report to the County Council in 1943 stated that only one third of the population was supplied with piped water, because of the scarcity of water sources on the island and difficulties of distribution to a scattered population. ${ }^{3}$

After the second world war housing improved and piped water was introduced throughout the county. According to the hygiene hypothesis this would have led to a rise in acute appendicitis rates at a time when its incidence was falling in the country as a whole.

\section{Methods}

The decennial censuses of England and Wales in 1951, 1961 , and 1971 recorded the presence in each house of certain amenities including piped water, water closets, hot water systems, and fixed baths. ${ }^{4}$ Operating theatre books for the three hospitals serving Anglesey-St Davids Hospital, Caernarfon and Anglesey General Hospital, and Holyhead Hospital-have been preserved for the years 1932 onwards. They record the name, age, sex, and address of each person undergoing surgery. We abstracted data on four operations, appendicectomy, tonsillectomy, repair of abdominal hernia, and surgery for perforated peptic ulcer, performed on people resident in Anglesey. Appendicectomies incidental to other operations, or in patients diagnosed as chronic appendicitis, were excluded. Because of the large amount of information we restricted attention to nine selected years. Operation rates were directly standardised for age and sex using the population of England and Wales in $1978-82$ as the standard.

Age-sex standardised appendicitis rates for Anglesey in 1978-82 were obtained from Hospital Activity Analysis data using criteria previously described. ${ }^{5}$ Trends in crude rates throughout England and Wales from 1957 onwards were taken from the Hospital In-patient Enquiry. ${ }^{6}$ Trends in Scotland were derived from an estimate of crude incidence in 193135 , based on National Health Insurance statistics, ${ }^{1}$ and age-sex standardised hospital discharge rates from 1961 onwards. $^{7}$ 
Results

Table 1 shows the changes in the percentage of households in Anglesey with the exclusive or shared use of piped water, a water closet, a fixed bath or a hot water system from 1951 onwards. Only for water closets and fixed baths were data recorded at all three censuses. At the 1951 census only $49 \%$ of households had piped water compared with $94 \%$ in England and Wales. The figures were lowest in the three rural districts, ranging from 24 to $32 \%$, and in Amlwch urban district, $46 \%$. In the other three urban districts and the metropolitan borough, they approached the national level. By 1961 there had been an increase in all districts so that $80 \%$ of all Anglesey households had piped water. The rural districts, however, remained below the national level. Trends in percentage of households with water closets in 1951 and 1961 followed those for piped water though lagging behind them in the rural districts. By 1971, 91\% of Anglesey households had water closets.

In 1951, only $30 \%$ of Anglesey households had a bath compared with $63 \%$ in England and Wales. Again the figures were lowest in the three rural districts, ranging from 17 to $23 \%$, and in Amlwch urban district, $23 \%$. In Holyhead, in contrast with the high percentage of households with piped water and water closets, only $42 \%$ had fixed baths. Figures for the other two urban districts and the metropolitan borough were around the national average. In 1961, the percentage of Anglesey households with baths had risen to 55 and in 1971 it was 83, the lowest figures continuing to be in the three rural districts and Amlwch. The trends in percentage of households with a hot water system, recorded in the 1961 and 1971 censuses only, were closely similar to those for baths.

Table 2 shows annual appendicitis rates in Anglesey in four periods, 1932 and 1935 combined, 1954/5, $1964 / 5$, and $1974 / 5$. In each district the rates rose between 1932/5 and 1964/5 with an overall doubling from $14 \cdot 0 / 10000$ to $29 \cdot 6 / 10000$. In $1974 / 5$ the rate fell to $26 \cdot 4 / 10000$. The lowest $1974 / 5$ rates were in Beaumaris $(14.5 / 10000)$ and Menai Bridge $(13 \cdot 2 / 10000)$. Rates were also below the average in Llangefni $(22 \cdot 6 / 10000)$ and in Valley rural district $(21 \cdot 6 / 10000)$ but in the latter they were rising rather than falling. The 1974/5 rate in Amlwch was high, $50 \cdot 1 / 10000$ and rising.

As in studies elsewhere, age-specific acute appendicitis rates in Anglesey were similar in the two sexes except at ages 15-29 years when they were higher among women, a difference usually attributed to a higher rate of removal of normal appendices. Both sexes and all ages showed the same general time trends.

The figure compares the Anglesey trend with those in England and Wales from 1957 onwards, and in Scotland from 1931 onwards. Data from Anglesey for 1939 , taken from the operating theatre records, are included, together with rates for Anglesey taken from Hospital Activity Analysis data for 1978-82. The rise and recent high rates in Anglesey contrast with the progressive decline in both England and Wales and Scotland.

Table 3 shows the trends for tonsillectomy, repair of abdominal hernias, and surgery for perforated peptic ulcer in Anglesey. Tonsillectomy and peptic ulcer surgery rates declined after 1954/5. Rates for abdominal hernia repair rose and declined similarly to those for appendicitis.

Table 1 Percentage of households in Anglesey with piped water, water closets, fixed baths, and hot water systems at three censuses: 1951, 1961, and 1971.

\begin{tabular}{|c|c|c|c|c|c|c|c|c|c|c|c|}
\hline & \multirow[b]{2}{*}{$\begin{array}{l}1951 \\
\text { Population }\end{array}$} & \multicolumn{3}{|l|}{1951} & \multicolumn{4}{|l|}{1961} & \multicolumn{3}{|l|}{1971} \\
\hline & & $\begin{array}{l}\text { Piped } \\
\text { water }\end{array}$ & $\begin{array}{l}\text { Water } \\
\text { closet }\end{array}$ & $\begin{array}{l}\text { Fixed } \\
\text { bath }\end{array}$ & $\begin{array}{l}\text { Piped } \\
\text { water }\end{array}$ & $\begin{array}{l}\text { Water } \\
\text { closet }\end{array}$ & $\begin{array}{l}\text { Fixed } \\
\text { bath }\end{array}$ & $\begin{array}{l}\text { Hot } \\
\text { water }\end{array}$ & $\begin{array}{l}\text { Water } \\
\text { closet }\end{array}$ & $\begin{array}{l}\text { Fixed } \\
\text { bath }\end{array}$ & $\begin{array}{l}\text { Hot } \\
\text { water }\end{array}$ \\
\hline \multicolumn{12}{|l|}{$\begin{array}{l}\text { Urban districts and } \\
\text { metropolitan borough }\end{array}$} \\
\hline $\begin{array}{l}\text { Amlwch } \\
\text { Beaumaris MB } \\
\text { Holyhead } \\
\text { Llangefni } \\
\text { Menai Bridge }\end{array}$ & $\begin{array}{r}2700 \\
2134 \\
10563 \\
2225 \\
1864\end{array}$ & $\begin{array}{l}46 \\
90 \\
91 \\
80 \\
84\end{array}$ & $\begin{array}{l}22 \\
92 \\
92 \\
82 \\
90\end{array}$ & $\begin{array}{l}23 \\
59 \\
42 \\
62 \\
63\end{array}$ & $\begin{array}{l}90 \\
97 \\
98 \\
96 \\
96\end{array}$ & $\begin{array}{l}87 \\
94 \\
93 \\
94 \\
94\end{array}$ & $\begin{array}{l}61 \\
76 \\
62 \\
86 \\
83\end{array}$ & $\begin{array}{l}65 \\
80 \\
68 \\
89 \\
86\end{array}$ & $\begin{array}{l}95 \\
98 \\
99 \\
99 \\
99\end{array}$ & $\begin{array}{l}83 \\
89 \\
87 \\
95 \\
96\end{array}$ & $\begin{array}{l}87 \\
94 \\
91 \\
96 \\
97\end{array}$ \\
\hline \multicolumn{12}{|l|}{ Rural districts } \\
\hline $\begin{array}{l}\text { Aethwy } \\
\text { Twrcelyn } \\
\text { Valley }\end{array}$ & $\begin{array}{r}10451 \\
8562 \\
12161\end{array}$ & $\begin{array}{l}24 \\
28 \\
32\end{array}$ & $\begin{array}{l}17 \\
19 \\
26\end{array}$ & $\begin{array}{l}17 \\
20 \\
23\end{array}$ & $\begin{array}{l}66 \\
66 \\
76\end{array}$ & $\begin{array}{l}44 \\
47 \\
58\end{array}$ & $\begin{array}{l}40 \\
44 \\
53\end{array}$ & $\begin{array}{l}42 \\
48 \\
56\end{array}$ & $\begin{array}{l}88 \\
83 \\
88\end{array}$ & $\begin{array}{l}80 \\
78 \\
82\end{array}$ & $\begin{array}{l}84 \\
81 \\
86\end{array}$ \\
\hline Anglesey & 50660 & 49 & 44 & 30 & 80 & 67 & 55 & 59 & 91 & 83 & 87 \\
\hline England and Wales & & 94 & 92 & 63 & 98 & 93 & 78 & 78 & 99 & 91 & 94 \\
\hline
\end{tabular}


Table 2 Average annual age-sex standardised rates for acute appendicitis per 10000 population in the districts of Anglesey

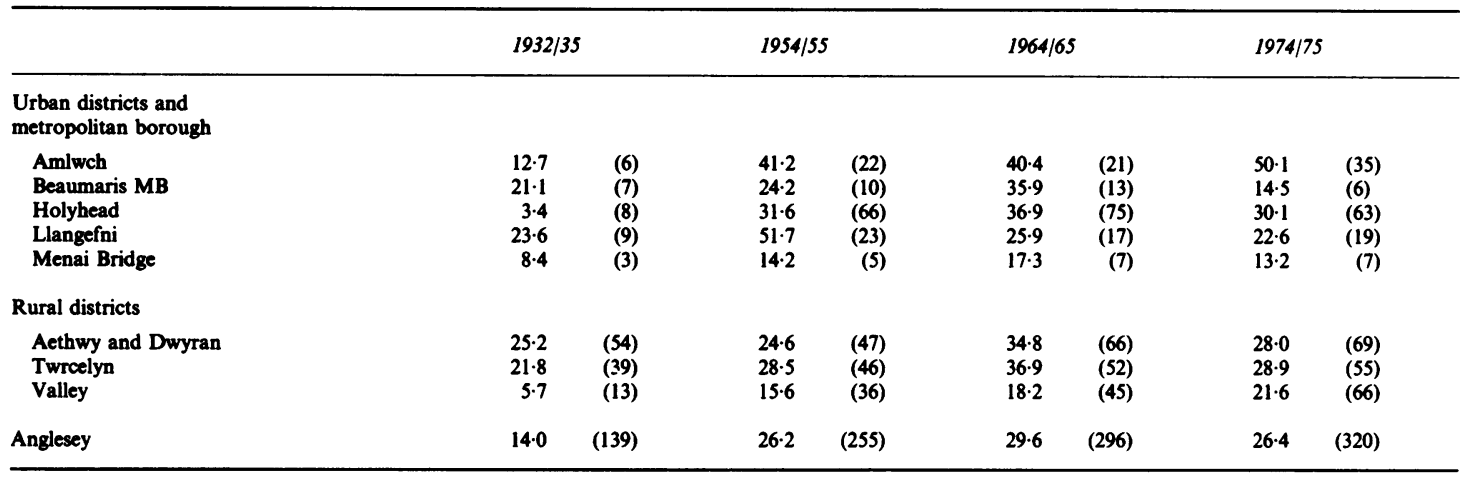

Numbers of cases in parentheses.

Table 3 Average annual age-sex standardised operation rates in Anglesey per 10000 population

\begin{tabular}{|c|c|c|c|c|c|c|c|c|}
\hline \multirow{2}{*}{$\frac{\text { Operation }}{\text { Appendicectomy }}$} & \multicolumn{2}{|c|}{$1932 / 5$} & \multicolumn{2}{|c|}{$1954 / 5$} & \multicolumn{2}{|c|}{$1964 / 5$} & \multicolumn{2}{|c|}{$1974 / 5$} \\
\hline & $14 \cdot 0$ & (139) & $26 \cdot 2$ & (255) & 29.6 & (296) & $26 \cdot 4$ & (320) \\
\hline Tonsillectomy & $14 \cdot 6$ & (163) & $27 \cdot 4$ & (293) & $22 \cdot 6$ & (251) & $11 \cdot 3$ & (155) \\
\hline Repair of abdominal hernia & 3.8 & (37) & 10.9 & (111) & $13 \cdot 0$ & (139) & 11.6 & (142) \\
\hline Surgery for perforated ulcer & - & (0) & 1.8 & (18) & 1.0 & (10) & 1.4 & (16) \\
\hline
\end{tabular}

Numbers of cases in parentheses.

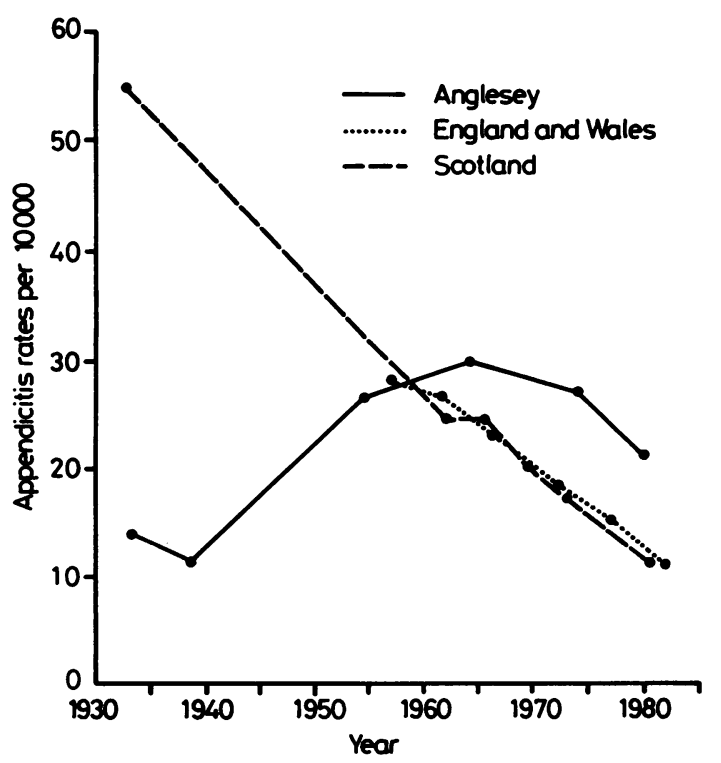

Trends in annual appendicitis rates in Anglesey from 1932 onwards compared with those in Britain (sources of data are described in the text).

\section{Discussion}

These findings show that the introduction of piped water throughout Anglesey, and the consequent steep increase in numbers of households with water closets, baths, and hot water systems, was accompanied by a rise in acute appendicitis rates. This occurred at a time when the incidence of appendicitis in Britain was falling.

The rise in operation rates for two elective procedures, tonsillectomy and abdominal hernia, between 1932/5 and 1954/5 indicates the improved access to surgery in Anglesey during the period (table 3). However, appendicitis is an acute, life-threatening emergency in young people whose treatment is given high priority when access to surgery is limited. Neither tonsillectomy nor emergency surgery for perforated peptic ulcer shared the rise in rates during 1954/5 and $1964 / 5$ seen for appendicectomy. It seems unlikely that trends in appendicectomy were determined by changing availability of surgery or surgical practice. The recording of home address in the operating theatre record books made it possible to exclude from the study visitors to the island. A review of a sample of appendicectomy records for Anglesey in 1985 showed 
that approximately $25 \%$ of removed appendices were pathologically normal. This is similar to percentages recorded elsewhere in the country. ${ }^{8}$

Although detailed records for Anglesey before 1932 have not been preserved, the annual 'House Surgeons' report of the Caernarfon and Anglesey Hospital records the rarity of appendicitis in the early part of the century (G Wynne Griffith, personal communication). The rise in appendicitis rates after the second world war was seen in all districts. The evidence that national rates began to fall in the 1930s comes from trends in mortality. ${ }^{1}$ Their continued fall thereafter was shown by hospital statistics, by general practitioners' consultation rates, and by a local survey. ${ }^{1}$ Though rates in Anglesey have begun to fall in the past 10 years, they remain high. In a survey of appendicitis in 1978-82 in 59 county districts throughout England and Wales, the highest rate found was in Anglesey, 20.6/10 000.5 In the British Isles, rates comparable to this are now found only in the northern and western regions of Ireland and in the Isle of Man. ${ }^{7}$ Similarly high rates were seen in northern Scotland during the early 1970 s but have since declined.

The differing pattern of appendicitis incidence within the five urban areas of Anglesey defines more closely the relation between improvements in amenities and trends in appendicitis rates. In Beaumaris, Llangefni, and Menai Bridge, the percentages of households with piped water, water closets, and baths were already around the national average by 1951 . In these places the combined appendicitis rates of $26.0 / 10000$ in $1964 / 5$ and $17 \cdot 9 / 10000$ in 1974/5 were similar to those in Britain as a whole (figure). Trends in Amlwch contrasted markedly. Here the percentages of households with any of the amenities in 1951 was well below the national average but increased sharply thereafter. Appendicitis rates rose to $50 \cdot 1 / 10000$ in $1964 / 5$, a value comparable to the rate in Scotland in 1931-35 as estimated from Health Insurance statistics (figure).

In Holyhead, the percentage of households with piped water and water closets in 1951 was around the national average, but the percentage with baths was well below average. Though this had increased by 1961 it, together with the percentage of households with hot water systems, remained below the average. Appendicitis rates in excess of $30 / 10000$ were sustained through to $1974 / 5$. These findings suggest that appendicitis rates depend more on provision of hot water systems and fixed baths than on piped water and water closets.

In the three rural districts, the percentage of households with any of the amenities in 1951 was low, and the subsequent increase was not sufficient to take the values up to those in the urban areas in either 1961 or 1971. Their combined appendicitis rates of $28 \cdot 2 / 10000$ in $1964 / 5$ and $25 \cdot 6 / 10000$ in $1974 / 5$ were above those in Britain as a whole (figure). The rates of 25.2 and $21.8 / 10000$ in two of the rural districts in $1932 / 5$ are high compared with rates in other districts but low in comparison with prevailing national rates.

The improvement in household amenities in Anglesey was not associated with other changes known to influence appendicitis rates. Among foods that have been suspected as causing the disease, current evidence supports only a possible protective effect of non-potato vegetables. ${ }^{57}$ Consumption in Anglesey is below the average for England and Wales, $141 \mathrm{~g} /$ person a day compared with 164 , but is well within the range for county districts. ${ }^{5}$ The diet of Anglesey is unremarkable. Dietary fibre consumption, for example, is above the national average at $22 \mathrm{~g} /$ person a day.

The 'hygiene' hypothesis suggests that initial improvements in hygiene, mainly determined by provision of household amenities, reduces exposure of young children to enteric organisms and is followed by a rise in appendicitis rates. Continued improvements in domestic hygiene, and possibly reduced overcrowding, lead to reduced encounters with enteric or respiratory triggering infections and hence a fall in appendicitis rates. The mechanisms by which reduced early exposure to enteric organisms alters the later response to triggering infection are not known. ${ }^{9}$ They could be more vigorous lymphoid hyperplasia in the appendicular wall with consequent luminal obstruction, or reduced ability of the appendiceal mucosa to prevent direct invasion by enteric organisms. An analogy has been suggested with paralytic poliomyelitis, also a consequence of reduced early childhood infection. ${ }^{1}$ It is of interest that, in Northern Ireland in 1956, before widespread poliomyelitis vaccination, the antibody status of children was not related to whether the house had a piped water supply. There was, however, a strong association between seropositivity and absence of a hot water system; this was independent of social class. ${ }^{10}$

We conclude that the rise and fall of appendicitis rates in Anglesey during the past $\mathbf{5 0}$ years is evidence that epidemics of the disease result from the introduction of modern hygiene practices, of which domestic hot water systems and fixed baths are important components. The magnitude and duration of the epidemic will depend on the speed with which the transition to full 'western' hygiene is effected.

We thank Dr G Wynne Griffith, formerly the Medical Officer of Health for Anglesey, for help and encouragement in this study. 


\section{References}

${ }^{1}$ Barker DJP. Acute appendicitis and dietary fibre: an alternative hypothesis. $\mathrm{Br} \mathrm{Med} J$ 1985; 290: 1125-27.

${ }^{2}$ Ministry of Health. Report of the Committee of Inquiry into the anti-tuberculosis service in Wales and Monmouthshire. London: HMSO, 1939.

${ }^{3}$ Raffety SR. Report on Anglesey water supply. Anglesey County Council, 1943.

${ }^{4}$ General Register Office. Census 1951, 1961, and 1971. County reports for Anglesey and housing tables. London: HMSO.
${ }^{5}$ Barker DJP, Morris J, Nelson M. Vegetable consumption and acute appendicitis in 59 areas in England and Wales. $\mathrm{Br}$ Med J 1986; 292: 927-30.

${ }^{6}$ Report on the hospital in-patient enquiry. London: HMSO, 1957 and following years.

${ }^{7}$ Morris J, Barker DJP, Nelson M. Diet, infection, and acute appendicitis in Britain and Ireland. $J$ Epidemiol Community Health 1987; 41: 44-9.

${ }^{8}$ Barker DJP, Liggins A. Acute appendicitis in nine British towns. Br Med J 1981; 283: 1083-5.

${ }^{9}$ Heaton KW. Aetiology of acute appendicitis. $\mathrm{Br}$ Med J 1987; 294: 1632-3.

${ }^{10}$ Backett EM. Social patterns of antibody to poliovirus. Lancet 1957; i: 778-83. 